\title{
Teaching for Creativity as Human Development toward Self-Actualization: The Essence of Authentic Learning and Optimal Growth for All Students
}

\author{
Majed Rabhan Wadaani ${ }^{1,2}$ \\ ${ }^{1}$ University of Kansas, Lawrence, KS, USA \\ 2Jazan University, Jazan, Saudi Arabia \\ Email: majedrwd@ku.edu, mwadaani@jazanu.edu.sa
}

Received 28 February 2015; accepted 8 May 2015; published 13 May 2015

Copyright (C) 2015 by author and Scientific Research Publishing Inc.

This work is licensed under the Creative Commons Attribution International License (CC BY).

http://creativecommons.org/licenses/by/4.0/

\section{c) (7) Open Access}

\begin{abstract}
Enhancing creativity is an important issue worldwide, but it is perceived and addressed differently from a population to another. Creativity is considered as an essential life skill, a major component of human intelligence, and the most important topic in the education of the gifted and talented students. Nations rely on youth to use their skills at the highest level possible to contribute to improving all life aspects including solving problems creatively, developing genuine innovations, and leading communities to productivity. Literature indicates that creativity should be nurtured in all students to become successful continued learners, and in gifted students to facilitate their talent development and extend their growth in optimal ways. This paper further discusses the nature of creativity, proposes a broad conceptualization of creativity based on the humanistic approach and positive psychology, and suggests teaching practices for fostering creativity in the general classroom.
\end{abstract}

\section{Keywords}

Teaching, Creativity, Intelligence, Human Development, Self-Actualization

\section{Introduction}

Allowing youth to use their intellectual potential at early levels of education is recommended; as special efforts at university levels often are not effective with students who have experienced continued earlier boredom and 
frustration (Stanley, 1991). Literature also indicates that creativity as an attitude toward life and development is more obvious and easier to nurture in young children than it is in older children and adults who have been affected by environments that encourage intellectual conformity, suppress creativity, and overlook talent potential (e.g., Torrance, 1995; Beghetto \& Kaufman, 2007; Sternberg, Kaufman, \& Grigorenko, 2008).

According to Sternberg and Kaufman (1998), children's multiple abilities would not be utilized if teaching and evaluation systems tend to undervalue creative and practical abilities. Teaching should not only be to help students learn facts and think critically about them; teaching should be for nurturing creative thinking, and facilitating overall development of students to become the mature adults they are capable of being (Sternberg, 2004). Sternberg (2006) explained that "teaching for creative as well as analytical and practical thinking combined enables children to capitalize on their strengths and to correct or to compensate for their weaknesses in order to be successfully intelligent individuals” (p. 94).

Creativity has been viewed as an important multifaceted phenomenon that can be developed for all students in different areas toward different levels (Davis, 2004). Treffinger, Young, Selby, \& Shepardson (2002) stated that "creativity can be expressed in a nearly infinite number of ways in human behavior and has its origins in several components of individual and social experience" (p. 5). Plucker, Beghetto, \& Dow (2004) added that "creativity is an important component of problem-solving, healthy social and emotional well-being, and scholastic and adult success" (p. 83). Therefore, teachers should not only teach creatively, but also teach for creativity; in order to motivate students to think effectively and become continued creative learners who can make well informed critical decisions and choices in unexpected situations (Torrance, 1995; Brinkman, 2010; Sternberg, 2010; Sriraman, Yaftian, \& Lee, 2011). As stated by Milgram and Hong (2009), "societies that do not make every effort to assure that the potential talents of young people are utilized are losing their most valuable natural resource; human capital” (p. 161).

This paper synthesizes rational support for teaching for creativity as philosophy of teaching that facilitates human development and self-actualization for all students. The major purpose is to contribute to enhancing school trends and teachers' attitudes toward teaching for creativity utilizing a broad conception of creativity, and internalizing positive beliefs about student capability for success.

\section{Creativity as a Human Phenomenon}

There have been attempts for many years to describe the construct and the principles of creativity which has resulted not only in different constructs of creativity, but also to different levels of creativity (Davis, Rimm, \& Siegle, 2011). Some of these different views are general and others overlap with other concepts such as giftedness, talent, and intelligence. The major four strands for inquiry on creativity were identified first by Rhodes (1961): the person, process, product, and the press (place/environment); known collectively as "The 4Ps model". These strands have been the focus of the majority of creativity definitions with different types of interactions and weights.

Humanistic psychologists Maslow $(1943,1968)$ and Rogers (1954) related creativity to self-actualization as a high level personal need that requires prior fulfillment of other basic needs including physiological, safety, social, and esteem needs. According to Maslow (1943) self-actualization refers to "the desire for self-fulfillment and being everything that one is capable of becoming” (p. 382). Rogers (1954) indicated that creativity emerges from the need of self-actualization that involves prerequisite personal and environmental conditions that support an internal locus of evaluation, feeling of worth, and freedom of expression. Maslow (1943) described that although creative behavior has multiple determinations, the products of creative people who are satisfied in their basic needs can be distinguished from the products of unsatisfied creative others.

Although it was not effectively utilized until decades later, the humanistic approach to understanding creativity has been prominent as the essence of broad contemporary conceptions of creativity. Davis (2004) pointed out the humanistic approach to creativity, through its relationship with self-actualization, provided the most influential concepts in the field of creativity; he summarized that Maslow and Rogers' theories of creativity indicate that the creative person is "a self-actualizing human being who is mentally healthy, self-accepting, democratic minded, fully functioning, and forward growing using all of his/her talents to become what he/she is capable of becoming" (p. 2).

Guilford $(1950,1966)$ discussed creativity with more emphasis on thinking processes especially divergent thinking in problem solving. According to Guilford (1950), creativity "represents patterns of primary abilities 
that can vary with different spheres of creative activity, and are based in multiple intellectual factors including sensitivity to problems, ideational fluency, flexibility of set, ideational novelty, synthesizing ability, analyzing ability, reorganizing or redefining ability, span of ideational structure, and evaluating ability” (p. 454). Guilford (1966) added that actual creative performance depends on multiple qualities and dimensions related to potentiality and on what the operating situation allows. The factor of creative potential was central in Guilford's view of creativity, as he (1966) indicated that it plays a significant role, and can be defined as "what an individual brings to a possible creative performance because of his personality structure” (p. 186).

Torrance $(1962,1993)$ also emphasized creative thinking process, he indicated that creativity is an important natural process that is based on human needs, and leads to effective learning and continued growth. He (1993) described creative thinking as "the process of sensing of difficulties, problems, gaps in information, missing elements, something askew; making guesses and formulating hypotheses about these deficiencies; evaluating and testing these guesses and hypotheses; possibly revising and retesting them; and, last, communicating the results ” (p. 233). According to Torrance's view (1962, 1993), creativity is the essence of scientific discoveries and inventions, and it is also in the realm of everyday living; as it is not only reserved for ethereal achieved heights of creation.

Amabile $(1982,1983,2001)$ discussed creativity as a dynamic process influenced significantly by the social environment factor. According to Amabile (1982), creativity can be regarded as "the quality of response, process, or products judged to be creative by appropriate observers familiar with the domain in which the response was articulated, the process implemented, or the product created" (p. 1001). She $(1983,2001)$ criticized theories of creativity that overemphasize personal talent as a premier source of individual creativity; and proposed her componential model that emphasizes hard work and passionate desire as factors that play central roles in creativity performance.

Amabile's componential model of creativity (1983) includes three basic intra-individual components. The first component is domain-relevant skills/expertise, which represents competencies and talents applicable to the domain or domains in which the individual is working. The second component is creativity-relevant processes, which represent personality characteristics, cognitive styles, and work habits that promote creativity in any domain. The third component is the intrinsic task motivation, the internally driven involvement in the task at hand, which can be influenced significantly by the social environment as an extra individual factor of creativity and innovation. Amabile and her collogues (1996) added that innovation does not depend only on individual creative ideas, but also requires creative ideas generated and matured by work teams within organizations that support successful implementation. Schools as educational organizations represent environments within which student creative thinking should be nurtured and ideas for innovative products should be supported.

Treffinger $(1988,1991)$ proposed the COCO model of creativity in which he indicated that creative productivity arises from dynamic interactions among four essential components: characteristics, operations, context, and outcomes. Characteristics include generating ideas, thinking deeper for more ideas, openness and courage to explore ideas, and listening to one's inner voice. Operations involve the strategies and techniques people employ to generate and analyze ideas, solve problems, make decisions, and manage their thinking. Context includes the culture, climate, situational dynamics such as communication and collaboration, and the physical environment in which one is operating. Outcomes are the products and ideas that result from people's efforts.

Sternberg \& Lubart $(1991,1996)$ analyzed creativity as an investment process; their Investment Theory of Creativity is a confluence theory according to which creative people are those who are willing and able to "buy low and sell high" in the realm of ideas. Sternberg (2006) described that " buying low means pursuing ideas that are unknown or out of favor but that have growth potential; and, often, when these ideas are first presented, they encounter resistance; the creative individual persists in the face of this resistance and eventually sells high, moving on to the next new or unpopular idea” (p. 87). According to the Investment Theory of Creativity (Sternberg \& Lubart, 1991, 1996), creativity requires a confluence of six distinct but interrelated resources: knowledge, intellectual abilities, styles of thinking, personality, motivation, and environment. Knowledge has been considered essential to produce original work and to go beyond what has been already known; it is also necessary because creativity can be domain specific. The intellectual abilities include synthetic, analytic, and practical abilities; using these three abilities, creative individuals can see connections, redefine problems, analyze ideas and judge their potential return, and present ideas in ways that show their values and get accepted for implementation. The styles of thinking represent the ways people prefer to use their intellectual abilities, such as the inventing legislative, implementing, and the evaluating style. 
Sternberg, O’Hara, \& Lubart (1997) indicated that everyone possesses every style to some degree, but individuals who want to be creative have to prefer and strengthen the inventing style of thinking which means doing things in novel ways. In addition to knowledge, ability, and style of thinking, individuals also need to have motivation for creativity in order to cope with difficulties faced and move forward with enjoyment. Creativity also requires a self-determined and risk-taking personality that persists for achievement, as well as an environment that supports the investment of ideas and spreads the risks.

Plucker, Beghetto, \& Dow (2004) described creativity as "the interaction among aptitude, process, and environment by which an individual or group produces a perceptible product that is both novel and useful as defined within a social context” (p. 90). Beghetto and Kaufman (2007) highlighted the relationship between learning and creativity; they indicated that "the interpretive and transformative process of information is a creative endeavor" (p. 73). They also pointed out that researchers and educators should broaden their conceptions of creativity, and explore how to "best support a lifetime of creative learning and expression” (p. 78). Tanggaard (2013) added that creativity should be viewed as "an everyday phenomenon resulting in continual processes of making the world” (p. 20). Therefore, it can be summarized that creativity can be expressed through different life skills of multiple aspects including the intellectual personal, environmental social, and innovative productivity aspect.

Davis, Rimm, \& Siegle (2011) concluded also that there are many intellectual abilities that contribute to creative potential; they described the major abilities of creativity that have appeared in creativity literature, especially in Guilford (1950) and Torrance's $(1962,1995)$ work, as the following:

- Fluency: The ability to produce many ideas in response to an open-ended problem or question, either verbal or nonverbal ones.

- Flexibility: The ability to make different approaches to a problem, think of ideas in different categories, or view a situation from several perspectives.

- Originality: statistical rarity or uniqueness and nonconformity.

- Elaboration: The ability to add details, develop, and implement a given idea.

Davis, Rimm, \& Siegle (2011) added that creativity is not limited to these common four abilities. They indicated that other important creative abilities include problem finding, problem sensitivity, problem defining, visualization, analogical thinking, evaluation, intuition, curiosity, independence, resisting premature closure, risk taking, logical thinking, seeing structure in chaos, discovering relationships, planning, prioritizing, and making good decisions. Literature also indicates that all individuals are capable of enjoying creative thoughts and production, but they may function at different levels of creativity; the following levels of creativity were adopted by Wilson (n.d.) from the work of A. Taylor (1959):

- Intuitive level: Creative expression for the intrinsic joy of creativity.

- Academic and technical level: Adding power to the creative expression by learning the techniques and skills related to the creative work.

- Inventive level: Going beyond skills and challenging the boundaries to practice untraditional experiments.

- Innovative level: Originality and out of the ordinary productions or ideas that have a guiding academic foundation.

- Genius level: The uniqueness of the ideas or the accomplishments that might have additional genetic aspects.

\section{Creativity and Human Intelligence}

Creativity has been discussed in relation to intelligence; however, literature indicates that "intelligence, as like as creativity, lacks a solid operational definitional foundation; definitions of intelligence still range from a neural efficiency perspective to the ability to adapt the self to the environment” (Batey \& Furnham, 2006, p. 364). Brody (2000) stated also that "contemporary theorists have not attained consensus about the definition of intelligence” (p. 30). Psychometric approaches of studying intelligence, in turn, have not provided a commonly accepted conclusion about its relationship with creativity (Jauk, Benedek, Dunst, \& Neubauer, 2013).

Factor analysis of human abilities provided different views of the quantity and quality of the factors accounting for intelligence components. The view of the single general ability factor " $g$ " that accounts for most human cognitive abilities has been presented earlier, criticized, utilized, and developed (e.g., Spearman, 1904, as cited in Brody, 2000). Guilford's (1956) multiple factors of intelligence and Cattell's (1963) theory of the fluid and crystallized intelligence provoked the field for more investigations and broader multi-aspect views and hierar- 
chical modeling. The study of Flynn (1984) on intelligence development through generations added more complexity and new directions toward understanding and developing intelligence; as he proposed that the environment, Flynn's effect, positively affects human intelligence as it develops. Flynn (2007) concluded that intelligence should be conceptualized like "the atom with multiple components that are held/blended together by the general intelligence factor, and smashed/splitted by the Flynn effect/environment effect on IQ gains over time" (p. 4).

In regard to creativity, broad theories of intelligence viewed creativity as an aspect and an outcome of intelligence; as they discussed intelligence to be a modifiable phenomenon with multiple factors (e.g., Guilford, 1956; Gardner, 1983; Sternberg, 1985). Guilford (1950) related creativity to divergent thinking process and included it as an aspect in his model of intelligence. In his model of intelligence, the Structure of Intellect, Guilford (1956) criticized the view of the single " $\mathrm{g}$ " factor of intelligence, and discussed a system of multiple factors of human intellectual abilities that were categorized under general headings including cognition (discovery), production (convergent and divergent thinking), and evaluation. Guilford also contributed to directing research to view intelligence as a multi-aspect phenomenon, as he (1956) indicated that "specifying a number of intelligences would be helpful in more understanding of human abilities” (p. 291).

Gardener $(1983,1999)$ was against the notion of determining human intelligence with a single general factor. He has a wide view of intelligence that considers creativity a parallel ability, with a focus on providing the conditions for the utilization of human multiple intelligences rather than just concerning about assessment. According to Gardner (1983), each human being possesses a blend, with different levels, of several basic intellectual competences/semi-independent intelligences that include linguistic, logical-mathematical, musical, bodily-kinesthetic, spatial, interpersonal, and intrapersonal intelligence. Gardner (1999) also discussed the possible existence of three additional kinds of intelligence, the naturalist, spiritual, and the existential intelligence. He also indicated that the discussion is still open for additional types of intelligences; as human intelligence is hard to capture.

According to Gardner (1999), creativity is a part of the intellectual realm that is parallel with, but different than intelligence. Gardner (1999) defined creativity as "the faculty of solving problems, creating products, or raising issues in a domain in a way that is initially novel, but is eventually accepted in on or more cultural setting” (p. 116). He (1999) pointed out that the major difference between creativity and intelligence is that creativity is a domain-specific activity that results in novel products or changes in the domain. Gardner (1999) admitted that the relationship between intelligence and creativity is complex, as he discussed different possible factors, kinds, and levels of creativity that emerged from personality theories and social psychology.

Sternberg's Triarchic Theory of Intelligence (1985) was one of theories that clearly included creativity as an aspect of intelligence. Sternberg's Triarchic Theory of Intelligence (1985) viewed creativity as an aspect among three interacting aspects of intelligence. The first aspect is analytical intelligence which involves information processing skills. The second is practical intelligence which involves using mental components of intelligence to adapt to, shape, or select environment that appropriate for oneself. The third aspect is creative intelligence which involves using mental components of intelligence to create new products or make new discoveries.

In terms of empirical research, the issue of whether current Intelligence Quotient tests (IQ) truly assess human intelligence, in addition to the difficulties in the assessment of creativity itself, has been the major challenge toward providing a commonly accepted conclusion about the relationship between human intelligence and creativity. Even with the reliance on IQ tests, Torrance (1993) argued that the possession of high intelligence as measured by IQ tests is not enough for outstanding creative success. He explained that creative thinking includes responding constructively to existing or new situations which may take time for incubation, rather than merely adapting to them using limited intellectual abilities.

Jauk, Benedek, Dunst, \& Neubauer (2013) stated that "investigations of the relationship between intelligence and creative potential provide a scattered view" (p. 214). They added that even studies of the prominent threshold hypothesis of the relationships between intelligence and creativity showed inconsistent results. They indicated that the threshold of 120 IQ points, as the minimum level of intelligence necessary for creativity, represents an educated guess; as empirical reliable supporting studies still are inadequate in this aspect.

Batey and Furnham, (2006) indicated that making unequivocal conclusions about the relationship between creativity and intelligence is unwise. They indicated that it is unwise because of inconsistent definitions provided for creativity and intelligence, the different types of psychometric instruments involved in the studies, as well as the influential traditional issues faced in such measurement studies including the design of IQ and crea- 
tivity tests, sample sizes, and statistical analyses. Kim (2005) concluded that "the negligible relationship between creativity and IQ scores indicates that even students with low IQ scores can be creative” (p. 65).

In conclusion, data obtained from empirical studies of the relationship between creativity and intelligence as measured by IQ tests reveals that both high IQ and average students have the potential to develop and expand their creative thinking skills (Kim, 2005). Research in this aspect also indicates that creativity is not solely dependent upon intelligence as studies showed that average students can score higher than high IQ students on some parts of creativity tests, as well as high IQ students are not always able to score consistently on all tasks of cognitive problem solving and creativity tests (Russo, 2004).

\section{Creativity as Human Development toward Self-Actualization}

Based upon what has been discussed in relevant literature about creativity, the researcher perceives creativity as "Human Development toward Self-Actualization" based upon Maslow’s (1943) definition of "Self-actualization" which refers to "the desire for self-fulfillment and being everything that one is capable of becoming" (p. 382). The humanistic self-actualization approach to creativity (Maslow, 1943; Rogers, 1954; Maslow, 1968) has been supported either explicitly or implicitly by many scholars. Davis (2004) admitted that the relationship between creativity and self-actualization is one of the most influential concepts in the field of creativity, and argued that creativity is a way of thinking and living that leads to personal development and a productive successful life.

Creativity is a process of growth, and the ultimate outcome of continued education. It represents ongoing overall development of humans/students that leads them to positively actualize themselves to reach the highest level possible appropriate for their special aptitudes, potentials, circumstances, and community needs. As the highest level of self-actualization may vary from an individual to another; students should be facilitated to develop positive belief systems related to their personal abilities, achievement goals, and future success; and lead them to keep an active and regenerated desire for self-actualization through unlimited high-level personal goals of achievement. Creativity, as human development, includes a broad range of personality characteristics, life skills, general mental skills, and domain-related skills (specialized creativity). Creativity as a process of thinking and production is included as an essential part of the 21st century skills necessary for success in such a changing world (The Partnership for 21st Century Skills, 2011); however, creativity in its comprehensive meaning actually represents all reported skills of the 21st Century including learning and innovation skills, information media and technology, life, and career skills.

Moreover, creativity is not limited to particular fields or exclusive in those who develop original ideasor products in such domains. Creativity is impeded in our daily life; we practice creativity explicitly and implicitly dealing with what we face every day, but at different levels. Creativity can be as simple as the feeling of being creative, the effective utilization of intellectual abilities, the successful personal and social living, the expression of unique performance in a special area, or it can go beyond the use of basic intellectual abilities by capitalizing on advanced skills for the development of original ideas and products that are innovative in a way that modifies or adds to the existing body of knowledge. Therefore, creativity is the crystalized aspect of human intelligence with its complex components and processes, not measured only by IQ tests; creativity is also the product of applied human intelligence with its multiple life dimensions, not measured only by standardized tests. The most successful creative person is the one who keeps positive beliefs and a growth mindset (Dweck, 2006), and works on continued development processes of his/her abilities to reach the highest level possible, so he/she can think and act creatively at a high level in all life aspects related to personality (cognitive, affective, and behavior altraits), environment, and productivity.

The academic aspect is significant in student life success. Demonstrating evolving skills related to a certain academic field can be a sign of creativity in this field; mathematical creativity for example. Sings of creativity in mathematics can be further developed in order to reach the highest level of creativity which represents the production of novel solutions that extend knowledge in the field. For students to achieve self-actualization, they need to be as creative as possible on both sides; general/personal/life creativity, and domain-specifics creativity, considering that the absence of original/novel production (innovation) does not mean the absence of creativity as a way of thinking and living.

Furthermore, it is not enough that students be successful in such academic subjects, and even to be eminent in a certain field of study or profession, without having developed personal and social skills that allow them to employ and direct their skills into the right path for personal and community development. Teaching in schools 
should be administrated to lead all students to be creative personally, socially, and academically with the same weight of importance, as interrelated factors of authentic achievement and success.

Teaching for creativity applies to all areas of study because personal and social skills of the successful life (general creativity) should be developed explicitly and implicitly through each subject class; as an important educational endeavor as the academic skills of each subject (domain-specific/specialized creativity). Creativity for elementary school age children should not be evaluated compared to levels of creativity of individuals at older ages. Signs of creativity in early ages might be simple and not worthy for some adult observers, but they are actually significant when they are evaluated compared to the abilities of peers at the same age, and can be further developed for promising results. Children's emerging abilities should be fostered through teaching for creativity which is the real achievement; creativity as real achievement means human development personally, socially, and academically toward self-actualization; self-actualization as a central ongoing human need.

\section{Teaching for Creativity}

Creativity is not a learning objective to be achieved and measured, but it is a personal component that all individuals should keep developing to the highest level possible. Teaching for creativity is not a teaching method, but it is a teaching philosophy that all teachers should adopt in order to facilitate continued development of human resources. Teachers should teach for creativity as a crystallized modifiable human capability with complex dimensions and an endless ceiling. Teaching for creativity is a philosophy through which multiple teaching methods can be modified or generated to lead students to develop their creativity in different contexts toward different levels. Most teaching methods that are considered in literature as effective methods in increasing student academic achievement can also be effective in developing student creativity if teachers' beliefs about teaching and achievement change.

When teachers understand their roles as a facilitator of optimal human development, and internalize positive beliefs about creativity as "the hub of real achievement" (Forster, 2012: p. 281), they can teach for creativity; as they will engage in group and self-learning for professional development that leads them to applicable best practices. Teachers can practice some teaching styles to create an environment of creativity that strengthens the teaching methods that they typically use. They may also use some additional teaching techniques to enhance creativity for all students, or they may design teaching methods to use specifically for fostering certain aspects of creativity.

Literature includes several teaching techniques, styles, methods, and models that have been recommended to develop creativity for all students. Gifted and talented students have been viewed to have high creativity potential, and as such, they need additional special care for maximizing their potential high creativity. Several models have been proposed specifically for developing certain thinking skills; however, some of these models have an emphasis in just some components of creativity such as divergent thinking and original products. Creativity is not only about divergent thinking, it is a construct that includes all aspects of human life that should be nurtured implicitly and explicitly in all contexts utilizing all available opportunities and resources for the overall optimal development of personality and social skills.

Nickerson (2010) pointed out that teaching for creativity can be carried out simply by avoiding negative beliefs and practices that discourage creativity; such as that are related to authority, ownership of ideas, making mistakes, questioning, tests, intelligence, originality, and student capability for development and success. He added that teaching for creativity is based on helping students to establish positive beliefs about their abilities and strengthen their attitudes toward creativity as a life skill. Therefore, teachers can develop student creativity even without the expenditure of extra time or the introduction of new curriculum.

Baer and Garrett (2010) pointed out that teaching for creativity and teaching specific content knowledge are not in opposition; they added that "teachers can successfully meet accountability standards and promote creativity in their classrooms” (p. 19). Treffinger, Schoonover, \& Selby (2013) indicated that teachers, who hold a belief that student creativity can and should be developed, can teach for creativity even if they face challenges and concerns related to the educational system. For example, they stated that "creativity and the U.S. Curriculum Common Core State Standards (CCSS) are not incompatible when approached effectively and some assumptions change such as those related to the standardized tests as being the only effective way of evaluation" (p. 254). Sheffield and her colleagues (2013) agreed that the CCSS for mathematics can be implemented in various ways to provide opportunities for developing creativity and nurturing advanced learners. Therefore, any teacher 
with positive beliefs and continued professional learning can construct learning activities that effectively integrate curriculum standards and tools for creative thinking (Treffinger, Schoonover, \& Selby, 2013; Sheffield et al., 2013).

Teaching for creativity is based on providing a positive school environment. Snyder, Lopes, \& Pedrotti (2011) emphasized the importance that teachers interact positively with students in order to identify and expand their strengths. Positive schooling, according to Snyder, Lopes, \& Pedrotti (2011), represents "an approach to education that consists of a foundation of care, trust, and respect for diversity, where teachers develop tailored goals for each student to engender learning and work with him or her to develop the plans and motivation to reach their goals; positive schooling includes the agendas of installing hope in students and contributing to the larger society” (p. 415).

The positive school environment that enhances student creativity requires that teachers provide a psychologically safe and motivating climate (Rogers, 1954; Amabile, 1996), that allows each student to think, try, share, use different ways, make mistakes, question, feel worthy, build autonomy, and achieve self-esteem. Psychological safety can be achieved by accepting and valuing all students' contributions, encouraging participation and collaboration, limiting competition, avoiding punitive assessment tests, and contributing to addressing personal and social student issues such as bullying, taunting, home and social status (Fairweather \& Cramond, 2010). Metcalf (2010) added that student feeling of safe is influenced by the language that teachers use, and the way in which student academic issues are addressed. She suggested solution-focused teaching to help students take responsibility for their issues, focus on solutions, and find opportunities for further development. Solution-focused teaching is based on the teacher as a facilitator of student success, by helping them externalize negative assumptions and internalize positive beliefs about their personalities, abilities, and responsibility for learning which is essential for creativity development.

Amabile and her colleagues (1996) believe that creativity can be encouraged through factors that promote intrinsic motivation with a positive sense of challenge and a focus on the work itself. Such important factors of creativity development that they declared include autonomy space, creativity encouragement, commitments with clear goals, mutual openness to ideas, and constructive challenge with appropriate reactions and feedback. Amabile (2001) added that policymakers and educators should not worry whether students have talent required to be provided with special education to achieve creative performance; rather, they should focus on creating opportunities for all individuals to master effective skills that help them develop their expertise in the domain and think creatively within environments that support active, deep engagement with challenging work, remembering that "creativity depends not only on brilliance and wit but also on discipline and passionate desire" (p. 335).

Sternberg (2010) indicated that creativity is "a habit that can be encouraged" (p. 394); he discussed essential principles of teaching for creativity. According to Sternberg (2010), the main components that prompt creativity include opportunities to engage in it, encouragement when students take advantage of these opportunities, and rewards when students think and behave creatively responding to such encouragement. He added that teaching for creativity requires teachers to be models of creative thinkers and performers for the purpose of lasting impacts on students' attitudes toward creativity.

The supportive, rewarding school environment of creative thinking, according to Sternberg (2010), entails using constructive practices of teaching and evaluation that allow space for creative thinking and behaviors; as creativity would be discouraged by the inappropriate use of conventional standardized tests that lead to conformity in both teachers' practices and student thinking. Some of the practices that he recommended to promote creativity include encouraging students to define and redefine their own problems and choices, question and analyze assumptions, find and work on what they love to do, practice presentation of their ideas and defending their positions, value knowledge and be continued learners, think across disciplines, identify and address obstacles, know about and appreciate creative individuals' lives and contributions, tolerate ambiguity, collaborate with others, take intellectual risks, learn from mistakes, and build self-efficacy.

Baer and Garrett (2010) believe that teaching for creativity is not only about developing divergent thinking. They explained that teaching for creativity is based on the balanced use of several effective theories and approaches of learning and teaching including the balanced utilization of intrinsic and extrinsic motivation, student-centered and teacher-centered, constructionist and transmissive ways of learning. For example, Amabile's Social Psychology Theory of creativity (Amabile, 1983, 1996) suggested that creativity is enhanced when students work in activities that are intrinsically motivating, and it is in determine when students work only for extrinsic rewards. As the balanced use of different approaches of teaching and learning is recommended, Baer and Garrett (2010) indicated that teachers can develop student creativity by giving more emphasis in activities that 
increase intrinsic motivation at certain times, and allow external rewards at other times, in order to capitalize on both approaches, and meet the curriculum standards of the educational system. External rewards being simple and unexpected are important conditions to ensure that intrinsic motivation is not affected negatively. Based on previous review of literature, creativity can be enhanced for all students using different methods and techniques; the major factor of successful teaching for creativity is that teachers internalize positive beliefs in student capability for success, and hold positive attitudes toward teaching for creativity in order to facilitate optimal growth for all students.

\section{Conclusion}

In conclusion, teaching for creativity is important to be adopted by teachers as philosophy of teaching in order to facilitate student overall development and self-actualization and thus contributing to nurturing future creative leaders who can positively affect their communities. The essence of teaching for creativity is providing a supportive learning environment that makes students feel safe, worthy, and encouraged to express their natural curiosity and abilities, with adequate support for developing productivity, personality, and social skills. These conditions are fundamentals for extending students' academic abilities and developing domain-specific creativity and talent. In order for teachers to teach for creativity, professional training and other features of support should be adequately available. Educational policy and strategic programs should be developed in light of teachers' needs in a way that ensures prior healthy conditions for successful implementation; this includes a clear mission and vision, continuous professional development, convinced satisfied staff, sufficient facilities, and a cooperative safe school climate that supports creativity.

\section{References}

Amabile, T. (1982). Social Psychology of Creativity: A Consensual Assessment Technique. Journal of Personality and Social Psychology, 43, 997-1013. http://dx.doi.org/10.1037/0022-3514.43.5.997

Amabile, T. (1983). The Social Psychology of Creativity: A Componential Conceptualization. Journal of Personality and Social Psychology, 45, 357-376. http://dx.doi.org/10.1037/0022-3514.45.2.357

Amabile, T. (1996). Creativity in Context: Update to the Social Psychology of Creativity. Boulder, CO: Westview.

Amabile, T. (2001). Beyond Talent. American Psychologist, 56, 333-336. http://dx.doi.org/10.1037/0003-066X.56.4.333

Amabile, T., Conti, R., Coon, H., Lazenby, J., \& Heroon, M. (1996). Assessing the Work Environment for Creativity. Academy of Management Journal, 39, 1154-1184. http://dx.doi.org/10.2307/256995

Baer, J., \& Garrett, T. (2010). Teaching for Creativity in an Era of Content Standards and Accountability. In R. Beghetto, \& J. Kaufman (Eds.), Nurturing Creativity in the Classroom (pp. 6-19). New York, NY: Cambridge University Press. http://dx.doi.org/10.1017/CBO9780511781629.003

Batey, M., \& Furnham, A. (2006). Creativity, Intelligence, and Personality: A Critical Review of the Scattered Literature. Genetic, Social, and General Psychology Monographs, 132, 355-429. http://dx.doi.org/10.3200/MONO.132.4.355-430

Beghetto, R., \& Kaufman, J. (2007). Toward a Broader Conception of Creativity: A Case for "mini-c” Creativity. Psychology of Aesthetics, Creativity, and the Arts, 1, 73-79. http://dx.doi.org/10.1037/1931-3896.1.2.73

Brinkman, D. (2010). Teaching Creatively and Teaching for Creativity. Arts Education Policy Review, 111, 48-50. http://dx.doi.org/10.1080/10632910903455785

Brody, N. (2000). History of Theories and Measurements of Intelligence. In S. Robert (Ed.), Handbook of Intelligence (pp. 16-33). Cambridge, UK: Cambridge University Press. http://dx.doi.org/10.1017/CBO9780511807947.003

Cattell, R. (1963). Theory of Fluid and Crystallized Intelligence: A Critical Experiment. Journal of Educational Psychology, 54, 1-22. http://dx.doi.org/10.1037/h0046743

Davis, G. (2004). Creativity Is Forever. Dubuque, IA: Kendall Hunt Publishing Company.

Davis, G., Rimm, S., \& Siegle, D. (2011). Education of the Gifted and Talented. Boston, MA: Pearson Education.

Dweck, C. (2006). Mindset: The New Psychology of Success. New York: Random House.

Flynn, J. (1984). The Mean IQ of Americans: Massive Gains 1932 to 1978. Psychological Bulletin, 95, 29-51. http://dx.doi.org/10.1037/0033-2909.95.1.29

Flynn, J. (2007). What Is Intelligence? Beyond the Flynn Effect. New York: Cambridge University Press. http://dx.doi.org/10.1017/CBO9780511605253

Forster, J. (2012). Creativity: The Hub of Real Achievement. Gifted Education International, 28, 281-299. http://dx.doi.org/10.1177/0261429411435108 
Gardner, H. (1983). Frames of Mind: The Theory of Multiple Intelligences. New York: Basic Books.

Gardner, H. (1999). Intelligence Reframed: Multiple Intelligences for the 21st Century. New York: Basic Books.

Guilford, J. (1950). Creativity. The American Psychologist, 5, 444-454. http://dx.doi.org/10.1037/h0063487

Guilford, J. (1956). The Structure of Intellect. Psychological Bulletin, 53, 267-293. http://dx.doi.org/10.1037/h0040755

Guilford, J. (1966). Measurement and Creativity. Theory into Practice, 5, 185-189. http://dx.doi.org/10.1080/00405846609542023

Jauk, E., Benedek, M., Dunst, B., \& Neubauer, A. (2013). The Relationship between Intelligence and Creativity: New Support for the Threshold Hypothesis by Means of Empirical Breakpoint Detection. Intelligence, 41, 212-221. http://dx.doi.org/10.1016/j.intell.2013.03.003

Kim, K. (2005). Can Only Intelligent People Be Creative? A Meta-Analysis. The Journal of Secondary Gifted Education, 16, 57-66.

Maslow, A. (1943). A Theory of Human Motivation. Psychological Review, 50, 370-396. http://dx.doi.org/10.1037/h0054346

Maslow, A. (1968). Toward a Psychology of Being. New York: Harper.

Metcalf, L. (2010). Teaching toward Solutions. Williston, VT: Crown House Publishing.

Milgram, R., \& Hong, E. (2009). Talent Loss in Mathematics: Causes and Solutions. In R. Leikin, A. Berman, \& B. Koichu (Eds.), Creativity in Mathematics and the Education of Gifted Students (pp. 149-161). Rotterdam: Sense Publishers.

Nickerson, R. (2010). How to Discourage Creative Thinking in the Classroom. In R. Beghetto, \& J. Kaufman (Eds.), Nurturing Creativity in the Classroom (pp. 1-5). New York: Cambridge University Press. http://dx.doi.org/10.1017/CBO9780511781629.002

Plucker, J., Beghetto, R., \& Dow, G. (2004). Why Isn’t Creativity More Important to Educational Psychologists? Potential, Pitfalls, and Future Directions in Creativity Research. Educational Psychologist, 39, 83-96. http://dx.doi.org/10.1207/s15326985ep3902_1

Rhodes, M. (1961). An Analysis of Creativity. The Phi Delta Kappan, 42, 305-310.

Rogers, C. (1954). Toward a Theory of Creativity. ETC: A Review of General Semantics, 11, 249-260.

Russo, C. F. (2004). A Comparative Study of Creativity and Cognitive Problem-Solving Strategies of High-IQ and Average Students. Gifted Child Quarterly, 48, 179-190. http://dx.doi.org/10.1177/001698620404800303

Sheffield, L., Johnson, S., Tassel-Baska, J., Adama, C., Cotabish, A., \& Mursky, C. (2013). Using the Common Core State Standards for Mathematics with Gifted and Advanced Learners. Waco, TX: Pruforck Press Inc. with NAGC, NCSM, and NCTM.

Snyder, C., Lopez, S., \& Pedrootti, J. (2011). Positive Psychology: The Scientific and Practical Explorations of Human Strengths. Thousand Oaks, CA: SAGE Publications, Inc.

Sriraman, B., Yaftian, N., \& Lee, K. (2011). Mathematical Creativity and Mathematics Education: A Derivative of Existing Research. In B. Sriraman, \& K. Lee (Eds.), The Elements of Creativity and Giftedness in Mathematics (pp. 119-130). Rotterdam: Sense Publishers.

Stanley, J. (1991). An Academic Model for Educating the Mathematically Talented. Gifted Child Quarterly, 35, 36-42. http://dx.doi.org/10.1177/001698629103500105

Sternberg, R. (1985). Beyond IQ: A Triarchic Theory of Human Intelligence. New York: Cambridge University Press.

Sternberg, R. (2004). Teaching College Students that Creativity Is a Decision. Guidance \& Counseling, 19, 196-200.

Sternberg, R. (2006). The Nature of Creativity. Creativity Research Journal, 18, 87-98. http://dx.doi.org/10.1207/s15326934crj1801_10

Sternberg, R. (2010). Teaching for Creativity. In R. Beghetto, \& J. Kaufman (Eds.), Nurturing Creativity in the Classroom (pp. 394-414). New York: Cambridge University Press. http://dx.doi.org/10.1017/CBO9780511781629.020

Sternberg, R., \& Kaufman, J. (1998). Human Abilities. Annual Review of Psychology, 49, 479-502. http://dx.doi.org/10.1146/annurev.psych.49.1.479

Sternberg, R., \& Lubart, T. (1991). An Investment Theory of Creativity and Its Development. Human Development, 34 , 1-31. http://dx.doi.org/10.1159/000277029

Sternberg, R., \& Lubart, T. (1996). Investing in Creativity. American Psychologist, 51, 677-688. http://dx.doi.org/10.1037/0003-066X.51.7.677

Sternberg, R., Kaufman, J., \& Grigorenko, E. (2008). Applied Intelligence. New York: Cambridge University Press. http://dx.doi.org/10.1017/CBO9780511611445

Sternberg, R., O’Hara, L., \& Lubart, T. (1997). Creativity as Investment. California Management Review, 40, 8-21. 
http://dx.doi.org/10.2307/41165919

Tanggaard, L. (2013). The Sociomateriality of Creativity in Everyday Life. Culture \& Psychology, 19, 20-32. http://dx.doi.org/10.1177/1354067X12464987

The Partnership for 21st Century Skills (2011). Framework for 21st Century Learning. Washington DC: P21. http://www.p21.org/storage/documents/1._p21_framework_2-pager.pdf

Torrance, E. P. (1962). Guiding Creative Talent. Englewood Cliffs, NJ: Prentice-Hall, Inc. http://dx.doi.org/10.1037/13134-000

Torrance, E. P. (1993). Understanding Creativity: Where to Start? Psychological Inquiry, 4, 232-234. http://dx.doi.org/10.1207/s15327965pli0403 17

Torrance, E. P. (1995). Insights about Creativity: Questioned, Rejected, Ridiculed, Ignored. Educational Psychology Review, 7, 313-322. http://dx.doi.org/10.1007/BF02213376

Treffinger, D. (1988). Components of Creativity: Another Look. Creative Learning, 2, 1-4.

Treffinger, D. (1991). Creative Productivity: Understanding Its Sources and Nurture. Illinois Council for Gifted Journal, 10, 6-8.

Treffinger, D., Schoonover, P., \& Selby, E. (2013). Educating for Creativity and Innoation: A Comprehensive Guide for Research-Based Practices. Waco, TX: Prufrock Press Inc.

Treffinger, D., Young, G., Selby, E., \& Shepardson, C. (2002). Assessing Creativity: A Guide for Educatores. Storrs, CT: The National Research Center on the Gifted and Talented.

Wilson, L. (n.d.). Levels of Creativity. http://thesecondprinciple.com/creativity/creativetraits/levels-of-creativity/ 